\title{
Serological investigation of ovine chlamydiosis in small ruminants in Western Turkey
}

\author{
Mehmet Engin Malal ${ }^{1}$, Mustafa Sencer Karagül ${ }^{2}$, Kadir Akar ${ }^{3}$ \\ ${ }^{1}$ Pendik Veterinary Control Institute, Aerobic Vaccines Production Laboratory, Pendik, Istanbul, Turkey \\ ${ }^{2}$ Kocaeli University, Kartepe Vocational School of Equine Science, Kartepe, Kocaeli, Turkey \\ ${ }^{3}$ Pendik Veterinary Control Institute, Brucella Reference Diagnostic and Vaccine Production Laboratory, Pendik, \\ Istanbul, Turkey
}

Received March 7, 2020

Accepted September 14, 2020

\begin{abstract}
The aim of this study was to investigate the seroprevalence of ovine chlamydiosis caused by Chlamydia abortus in sheep and goats in Western Turkey. Chlamydial abortion causes late term abortions with a worldwide occurence particularly in sheep and goats; it also leads to significant financial losses. Seroepidemiological studies provide useful data regarding the prevalence of the disease. Isolation of Chlamydia abortus as the causative agent of the disease is a time consuming and laborious procedure requiring appropriate biosafety measures. Serological methods are commonly used for routine diagnosis and enzyme-linked immunosorbent assay is generally recommended for surveillance studies. In this study, a total of 833 blood samples obtained from 126 herds of sheep and goats located in all provinces of the Marmara region, Western Turkey, were analyzed. Total seroprevalence was found to be $25.81 \%$ through enzyme-linked immunosorbent assay. However, the proportion of seropositive herds was observed at $62.70 \%$, which is higher than the total seroprevalence. This study confirms the presence of Chlamydia abortus exposure in sheep and goat herds in the Marmara region and provides original seroprevalence data in the provinces, which have not been reported so far. The data gathered are useful for the evaluation and elaboration on the seroprevalence of chlamydiosis in small ruminants in the Marmara region, Turkey.
\end{abstract}

Chlamydia abortus, enzootic abortion, seroprevalence, zoonosis

Chlamydia is an important pathogen for both human and animal health as it is commonly reported in stillbirth or abortion cases of livestock (Jonker 2004; Givens and Marely 2008). The family Chlamydiaceae is composed of 11 species belonging to the single genus Chlamydia (Sachse et al. 2015). Among these species, C. abortus is the causative agent of ovine chlamydiosis, also called as 'enzootic abortion of ewes' (EAE) or 'ovine enzootic abortion' (OIE 2018). The disease mainly occurs in sheep and goats endemically; however, less frequently there are sporadic infections associated with other species such as cattle, pigs, horses, deer, and yaks (Wang et al. 2001; Longbottom and Coulter 2003; Stuen and Longbottom 2011; Chen et al. 2014; OIE 2018).

Chlamydia species lead to fertility problems, conjunctivitis, respiratory diseases, polyarthritis and other complications in animals and humans (Rodolakis et al. 1998). Enzootic abortion results in late term abortions, weak offsprings and stillbirth in sheep and goats (OIE 2018).

Chlamydial abortion is responsible for huge reproductive losses in different countries of the world. Australia and New Zealand could be given as an example of countries that are free from the disease (Aitken and Longbottom 2007; Stuen and Longbottom 2011; Essig and Longbottom 2015; Selim 2016). Effects of the disease grow particularly more adverse in herds which are intensively managed at the time of lambing (Longbottom and Coulter 2003; Aitken and Longbottom 2007; Stuen and Longbottom 2011; Essig and Longbottom 2015). Aborted materials, birth products, vaginal secretions, and uterine

Address for correspondence:

Mustafa Sencer Karagul

Kocaeli University

Kartepe Vocational School of Equine Science

41080, Kartepe, Kocaeli, Turkey

Phone: +902623733327

E-mail: sencer.karagul@kocaeli.edu.tr

http://actavet.vfu.cz/ 
discharges are the main means of transmitting the pathogen. The disease also spreads by other secretions and excretions such as faeces (Rodolakis et al. 1998; Aitken and Longbottom 2007; Selim 2016). This contamination constitutes the source of infection for susceptible hosts such as ewes and humans (Rodolakis et al. 1998; Nietfeld 2001; Aitken and Longbottom 2007; Essig and Longbottom 2015). When a clean flock with susceptible hosts is exposed to the pathogen, it leads to fewer abortion cases in the first year of exposure. The following year, an abortion storm is expected in consequence of the disease (Rodolakis et al. 1998; Longbottom and Coulter 2003; Aitken and Longbottom 2007; OIE 2018). In humans, the disease has many different symptoms including subclinical infection and acute flue-like disease (OIE 2018). The pathogen can cause serious infections and fatal illnesses in pregnant women due to chlamydial induced abortions (Jorgensen 1997; Longbottom et al. 2002; Aitken and Longbottom 2007; Essig and Longbottom 2015).

Different staining or antigen-detection methods can be used to detect Chlamydia in smears and tissues. Identification of the agent could also be done by polymerase chain reaction (PCR) based methods including real-time PCR. Isolation of the organism is possible in cell cultures or chicken embryos (OIE 2018); however, the requirements of appropriate biosafety and biosecurity regulations must be carried out during isolation and identification because of the zoonotic risk of the organism (Stuen and Longbottom 2011; OIE 2018). Therefore, serological diagnosis is a suitable choice to determine the prevalence of the infection through monitoring. ELISA is accepted as a validated and recommended method for this purpose (OIE 2018). Another serological test, complement fixation test (CFT) has been widely used as a traditional procedure to show the presence of EAE (Longbottom et al. 2002; Otlu et al. 2007; Selim 2016; OIE 2018). However, it is no longer recommended as it is possible to get false positive results because of cross-reaction between $C$. abortus and $C$. pecorum and other gram negative bacteria (Longbottom et al. 2002; Gokce et al. 2007; OIE 2018).

This study aimed to reveal the seroprevalence of the disease among sheep and goats in 11 provinces of the Marmara region, Western Turkey. The Marmara region (Fig. 1), has the highest population with twenty-five million people including approximately more than a quarter of the total population in Turkey. The region has significant potential for small ruminant farming with more than four million animals (TUIK 2020). Considering the zoonotic characteristic of chlamydiasis and lack of serology studies of EAE from Western Turkey, the Marmara region has been selected for this seroprevalence study. The study could be a starting point for future research and control studies to be carried out nationwide.

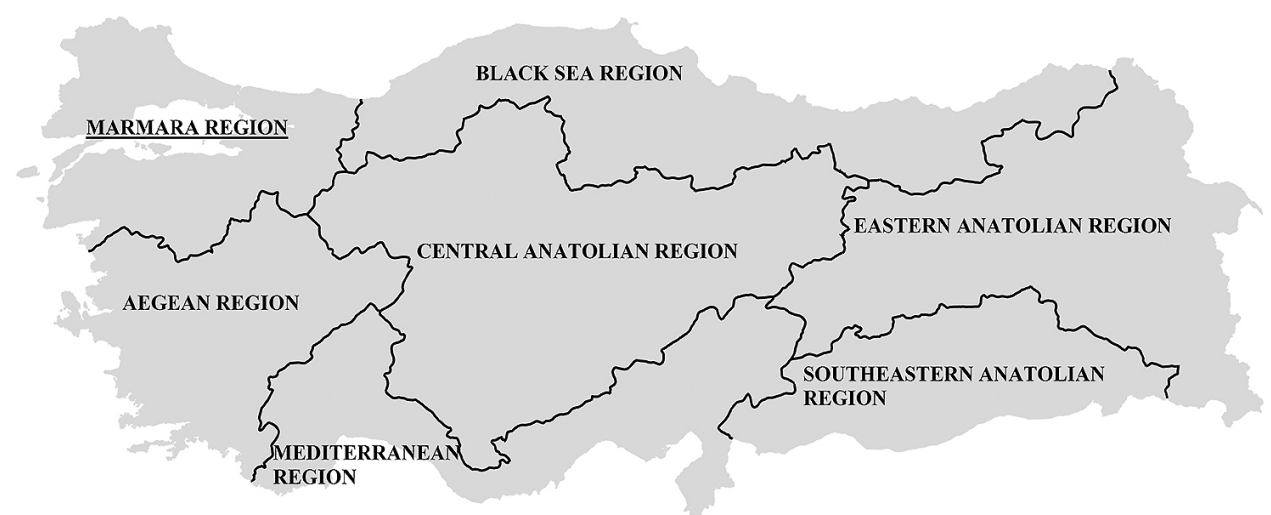

Fig. 1. The geographical regions of Turkey. 


\section{Materials and Methods}

The study was conducted at the Pendik Veterinary Control Institute (PVCI), Istanbul, Marmara Region, Turkey. Research was approved by the Local Ethics Committee for Animal Experiments, PVCI, Istanbul, Turkey (Ethics Committee Decision No: 09-1/2018). A total of 833 samples obtained from 126 herds which were located in 117 villages/districts of 63 towns in all 11 provinces of the Marmara region were used. Seventy to eighty-five samples were collected from each province in order to include different towns and villages in each province. All the sheep and goats were female (randomly selected) between 1.5 and 7 years old. Females were selected because the disease often manifests as abortions (Jonker 2004). Totally, 205 and 628 blood samples were collected from goat and sheep herds, respectively.

A small number of animals (16 sheep and 7 goats) had a history of abortion. The sample size in this study was calculated in accordance with EpiTools epidemiological calculators (https://epitools.ausvet.com.au/). In the calculation, the values used were as follows: assumed prevalence of $50 \%$, desired precision of $5 \%$, and confidence level of $99 \%$. The distribution of samples is shown in Table 1.

Table 1. The distribution of the samples regarding the province and animal species.

\begin{tabular}{|c|c|c|c|c|c|}
\hline Provinces & $\begin{array}{c}\text { Number of } \\
\text { municipalities }\end{array}$ & $\begin{array}{c}\text { Number of } \\
\text { herds }\end{array}$ & $\begin{array}{c}\text { Number of } \\
\text { sheep samples }\end{array}$ & $\begin{array}{c}\text { Number of } \\
\text { goat samples }\end{array}$ & $\begin{array}{c}\text { Total number } \\
\text { of samples }\end{array}$ \\
\hline Balikesir & 9 & 12 & 76 & 2 & 78 \\
\hline Bilecik & 6 & 12 & 60 & 25 & 85 \\
\hline Bursa & 5 & 7 & 46 & 26 & 72 \\
\hline Canakkale & 5 & 10 & 39 & 31 & 70 \\
\hline Edirne & 8 & 12 & 67 & 3 & 70 \\
\hline Istanbul & 6 & 11 & 50 & 35 & 85 \\
\hline Kirklareli & 6 & 15 & 49 & 21 & 70 \\
\hline Kocaeli & 4 & 12 & 60 & 10 & 70 \\
\hline Sakarya & 6 & 12 & 39 & 39 & 78 \\
\hline Tekirdag & 5 & 10 & 60 & 10 & 70 \\
\hline Yalova & 3 & 13 & 82 & 3 & 85 \\
\hline TOTAL & 63 & 126 & 628 & 205 & 833 \\
\hline
\end{tabular}

The sera were kept at $-20{ }^{\circ} \mathrm{C}$ until testing. The commercial ELISA test kit including positive and negative control sera (Chlamydophila abortus Antibody Test Kit, IDEXX Laboratories, Westbrook, Maine, USA) was used to detect the presence of specific antibodies against $C$. abortus. The method was implemented in accordance with the manufacturer's instructions. Dilutions of sera at 1:400 were prepared as recommended. Monoclonal anti-ruminant-IgG conjugated with horseradish peroxidase was utilized to be able to measure specific antibodies (Samkange et al. 2010).

ELISA reader (Rayto RT-6000) was used to measure the optical densities (OD) of the tested samples, negative and positive control at $450 \mathrm{~nm}$. The results were interpreted according to the manufacturer's recommendation; namely, $\mathrm{S} / \mathrm{P} \leq 30 \%$ were considered to be negative, $30-40 \%$ were considered to be suspect and $\geq 40 \%$ were considered to be positive (Samkange et al. 2010; Benkirane et al. 2015; Špičić et al. 2015). Pearson chi-square analysis was used to find whether $C$. abortus seropositivity was statistically significant according to provinces.

\section{Results}

As a result of the study, 215 from 833 serum samples were positive for Chlamydia abortus, and 618 were negative (Table 2). Seropositivity in sheep and goats were found to be $29.14 \%(n=183)$ and $15.61 \%(n=32)$, respectively. Total seroprevalence was observed as $25.81 \%(\mathrm{n}=215$; Table 2$)$. In addition, 79 herds out of $126(62.70 \%)$ had at least one seropositive result. Seropositivity was found to be $39.13 \%(n=9)$ in animals with a history of aborting. The prevalence among provinces varied between $14.12 \%$ and $34.62 \%$. In 9 out of 11 provinces, the prevalence value was found to be more than $20 \%$. The highest provincial seropositivity was obtained in Balıkesir with $34.62 \%$, and it was followed by Kocaeli and Edirne with $34.29 \%$ and $32.86 \%$, respectively. The lowest 
Table 2. The provincial seroprevalence and the proportion of seropositive herds.

\begin{tabular}{lcccc}
\hline Province & $\begin{array}{c}\text { Number of } \\
\text { positive samples }\end{array}$ & $\begin{array}{c}\text { Number of } \\
\text { negative samples }\end{array}$ & $\begin{array}{c}\text { Total } \\
\text { seroprevalence (\%) }\end{array}$ & $\begin{array}{c}\text { Seropositive } \\
\text { herds }(\%)\end{array}$ \\
\hline Balıkesir & 27 & 51 & 34.62 & 91.67 \\
Bilecik & 18 & 67 & 21.18 & 58.33 \\
Bursa & 21 & 51 & 29.17 & 71.43 \\
Canakkale & 18 & 52 & 25.71 & 50.00 \\
Edirne & 23 & 47 & 32.86 & 75.00 \\
Istanbul & 13 & 72 & 15.29 & 54.54 \\
Kirklareli & 21 & 49 & 30.00 & 60.00 \\
Kocaeli & 24 & 46 & 34.29 & 75.00 \\
Sakarya & 24 & 54 & 30.77 & 66.67 \\
Tekirdag & 14 & 56 & 20.00 & 60.00 \\
Yalova & 12 & 73 & 14.12 & 30.77 \\
Marmara region & 215 & 618 & 25.81 & 62.70 \\
\hline
\end{tabular}

Table 3. The chi-square results.

\begin{tabular}{lcc}
\hline Pearson's chi-square test & X2 & P \\
\hline Provinces and total seropositivity & 23.095 & 0.010 \\
Provinces and herd seropositivity & 13.012 & 0.223 \\
\hline
\end{tabular}

seroprevalence was found in Yalova with $14.12 \%$ (Table 2). However, the percentages of the seropositive herds in provinces were considerably higher and varied between $58.33 \%$ and $91.67 \%$.

Significance $(P<0.05)$ was found between provinces in terms of total seropositivity. However, herd seropositivity was not found to be significant $(P>0.05)$. The results of the statistical analysis are shown in Table 3.

\section{Discussion}

Foetal death associated with abortion is an important issue because of financial losses and public health safety (Jonker 2004; Benkirane et al. 2015) not only in Turkey (Kalender et al. 2013) but also all around the world (Gokce et al. 2007). In Turkey, abortions primarily occur as a result of brucellosis (Küçükayan et al. 2007; Otlu et al. 2007); however, chlamydial abortion is also considered to be one of the major reasons for abortions in livestock (Küçükayan et al. 2007; Öztürk et al. 2016). In this respect, considering the enzootic abortion disease, a regular serological screening is a very useful tool to determine the infected and carrier animals in herds (Gökçe et al. 2007; Otlu et al. 2007; OIE 2018). In the past, several surveillance studies in central and eastern regions of Turkey revealed the extent of the disease in the country's livestock in the last two decades (Duman and Durak 1998; Çaya et al. 2006; Gökçe et al. 2007; Küçükayan et al. 2007; Otlu et al. 2007; Kalender et al. 2013; Öztürk et al. 2016). To the best of our knowledge, this is the first study investigating the seroprevalence of $C$. abortus in a western region the Marmara region in Turkey. Therefore, the results obtained within this study might be useful for a comparison of the seroprevalence in western Turkey with the other parts of the country for prospective research.

According to the previous studies conducted in central and eastern parts of Turkey, the seropositivity of C. abortus in sheep flocks varied between $1.81 \%$ and $32 \%$ (Duman and Durak 1998; Çaya et al. 2006; Gökçe et al. 2007; Küçükayan et al. 2007; Otlu et al. 2007; Kalender et al. 2013; Öztürk et al. 2016). For instance, according to the findings of the studies carried out in the Kars province located in north-eastern Turkey, the 
seroprevalance was found to be 5.38\% and 13.98\% (Gökçe et al. 2007; Otlu et al. 2007). The total prevalence belonging to some provinces of southeastern and Mediterranean regions was $19.5 \%$ (Çaya et al. 2006). In the studies carried out in the central region of Turkey, the obtained values were 20\% and 1.81\% (Duman and Durak 1998; Küçükayan et al. 2007). The seroprevalence among sheep herds (29.28\%) found in this study was higher than that of most of the previous studies. In addition, total seroprevalence of goat herds $(15.61 \%)$ was also significantly high. There might be differences between seroprevalence values belonging to the cities of the same region, and even districts of the same province (Çaya et al. 2006; Gökçe et al. 2007; Otlu et al. 2007; Öztürk et al. 2016). In this study, differences between provinces were observed and even total seropositivity between provinces was significant. This significance might be due to the values of Balıkesir (Highest Standardized Residual: 1.5) and Yalova (Lowest Standardized Residuals: -2.1).

The samples tested in the previous studies belonged to the animals with a history of abortion. In this study, on the other hand, the majority of samples include animals with no abortion history and still, it led to higher seropositivity in aborting animals $(39.13 \%, \mathrm{n}=9)$. In a recent study investigating a Mediterranean province, the individual prevalence in sheep was $32 \%$ and $80 \%$ among herds (Öztürk et al. 2016). Similarly, in our study, herd seropositivity was found to be higher than the total seroprevalence.

Individual prevalence in this study was found to be higher than that of the neighbouring countries such as Iran (5.71\%) (Borujeni et al. 2019), Iraq (11.41\%) (Fahad and Salman 2017) and Greece (14.9-21.2\%) (Bisias et al. 2009) and those of some other countries such as Saudi Arabia (9.07\%) (Abd El-Razik et al. 2011) and Costa Rica (5.29\%) (VillagraBlanco et al. 2015). On the contrary, a higher herd prevalence than in this study was found in studies carried out in Slovakia (63.2\%) (Trávníček et al. 2003), Algeria (70.4\%) (Hireche et al. 2014), Brasil (77.7\%) (Pinheiro Junior et al. 2010), Ethiopia (89.17\%) (Gebretensay et al. 2019), and Morocco (91\%) (Benkirane et al. 2015). Borujeni et al. (2019) stated that the reasons behind such differences among countries might stem from some factors such as geographical conditions, management systems and methods utilized to detect antibodies of C. abortus.

In general, the high percentages obtained illustrate the host's susceptibility to the pathogen. This might be taken into consideration for the regional precautions and possible eradication programmes aming to decrease the abortion storms caused by C. abortus.

A vaccination programme which supports strategies fighting enzootic abortions and which can bring about a decline in abortion cases should be taken into consideration as suggested by previous studies (Otlu et al. 2007). Chlamydia abortus can often be introduced into small ruminant herds with the addition of new animals. Therefore, new imports of animals should come from the herds free of the infection (Aitken and Longbottom 2007; Stuen and Longbottom 2011). This point indicates the importance of disease-free certification programmes. Separating the infected animals from others and replacing them with healthy animals is also very important in order to establish control and eradication programmes while reducing contamination on the pasture, the spread of the pathogen, economic loss and public health risk (Otlu et al. 2007).

It is impossible to maintain clean herds or create healthy herds without regular serological screening. The data gathered from seroepidemiological research like our study and the previous ones may guide and contribute to the control strategies against chlamydial abortion. The results of the study have confirmed the occurrence of chlamydial infection in sheep and goat herds in all of the 11 provinces of the Marmara region. The values of total seroprevalence and percentage of seropositive herds indicate that there is a risk for this zoonosis and necessary control and measuring systems should be established so as to decrease the existent risk and farmers should be educated about this disease. 


\section{References}

Abd El-Razik KA, AL-Humiany AA, Ahmed WM, Barakat AMA, ELfadaly HA 2011: Investigations on non Brucella abortifacients in small ruminants in Saudi Arabia with emphasis on zoonotic causes. Glob Vet 6: 25-32

Aitken ID, Longbottom D 2007: Chlamydial abortion. In: Aitken ID (Ed.): Diseases of Sheep, $4^{\text {th }}$ edn. Blackwell Scientific Ltd, Oxford, pp. 105-112

Benkirane A, Essamkaoui S, El Idrissi A, Lucchese L, Natale A 2015: A sero-survey of major infectious causes of abortion in small ruminants in Morocco. Vet Ital 51: 25-30

Borujeni MP, Bakhtiari NM, Hajikolaei MRH, Mousavi MS 2019: Chlamydia abortus infection in goats in the southwest of Iran. Revue Méd Vét 170: 9-14

Bisias G, Burriel A, Boutsini S, Kritas S, Leontides L 2009: A serological investigation of some abortion causes among small ruminant flocks in Greece. Internet J Vet Med 8: 1-5

Chen Q, Gong X, Zheng F, Cao X, Li Z,Zhou J 2014: Seroprevalence of Chlamydophila abortus infection in yaks (Bos grunniens) in Qinghai, China. Trop Anim Health Prod 46: 503-507

Çaya H, Aslantaş Ö, İyisan AS, Mirioğlu M, Tunca ŞT 2006: Chlamydophila abortus'a (Chlamydia psittaci serotype 1) karşı oluşan antikorların mikrokomplement fikzasyon (mCFT) ve Enzyme-Linked Immunosorbent Assay (ELISA) ile araştırılması. Etlik Vet Mikrobiyol Derg 17: 7-12

Duman R, Durak Y 1998: Investigation on Chlamydia psittaci infections causing abortion in sheep in Konya district using complement fixation test. Turk J Vet Anim Sci 22: 511-515

Essig A, Longbottom D 2015: Chlamydia abortus: New aspects of infectious abortion in sheep and potential risk for pregnant women. Curr Clin Microbiol Reports 2: 22-34

Fahad OA, Salman SS 2017: Survey for ovine and caprine chlamydiosis by ELISA in AL-Fallujah city/Iraq. J Entomol Zool Stud 5: 322-326

Gebretensay A, Alemayehu G, Rekik M, Biruk Alemu B, Haile A, Rischkowsky B, Aklilu F, Wieland B 2019: Risk factors for reproductive disorders and major infectious causes of abortion in sheep in the highlands of Ethiopia. Small Rum Res 177: 1-9

Givens MD, Marely MSD 2008: Infectious causes of embryonic and fetal mortality. Theriogenology 10: 10-16

Gökçe HI, Kacar C, Genc O, Sozmen M 2007: Seroprevalence of Chlamydophila abortus in aborting ewes and dairy cattle in the North-East part of Turkey. Bull Vet Inst Pulawy 51: 9-13

Hireche S, Bouaziz O, Djenna D, Boussena S, Aimeur R, Kabouia R, Bererhi el H 2014: Seroprevalence and risk factors associated with Chlamydophila spp. infection in ewes in the northeast of Algeria. Trop Anim Health Prod 46: 467-473

Jonker HF 2004: Fetal death: comparative aspects in large domestic animals. Anim Rep Sci 82-83: 415-430

Jorgensen DM 1997: Gestational psittacosis in a Montana sheep rancher. Emerg Infect Dis 3: 191-194

Kalender H, Kılıç A, Eröksüz H, Muz A, Kılınç Ü, Taşdemir B 2013: Identification of Chlamydophila abortus infection in aborting ewes and goats in EasternTurkey. Rev Med Vet (Toulouse) 164: 295-301

Küçükayan U, Dakman A, Ülker U, Müştak K 2007: Koyun kan serumları ve bakteriyel atık etkenleri yönünden incelenmesi. Etlik Vet Mikrobiyol Derg 18: 11-16

Longbottom D, Coulter LJ 2003: Animal chlamydioses and zoonotic implications. J Comp Pathol 128: 217-244

Longbottom D, Fairley S, Chapman S, Psarrou E, Vretou E, Livingstone M 2002: Serological diagnosis of ovine enzootic abortion by enzyme-linked immunosorbent assay with a recombinant protein fragment of the polymorphic outer membrane protein POMP90 of Chlamydophila abortus. J Clin Microbiol 40: 4235-4243

Nietfeld JC 2001: Chlamydial infections in small ruminants. Vet Clin North Am Food Anim Pract 17: $301-314$

OIE 2018: World Organisation for Animal Health, Manual of Diagnostic Tests and Vaccines for Terrestrial Animals. Chapter 2.7.6. Enzootic abortion of ewes, Ovine chlamydiosis, Infection with Chlamydia abortus, pp. 1-10

Otlu S, Sahin M, Unver A, Celebi O 2007: Detection of Brucella melitensis and Chlamydophila abortus antibodies in aborting sheep in the Kars province of Turkey. Bull Vet Inst Pulawy 51: 493-495

Öztürk D, Türütoğlu H, Kaya M 2016: Burdur ilindeki koyunlarda Chlamydophila abortus enfeksiyonunun seroprevalans1. MAE Vet Fak Derg 1: 17-20

Pinheiro Junior JW, Mota RA, Piatti RM, Oliveira AA, da Silva AM, de Oliveira Abreu SR, Anderlini GA, Valença RM 2010: Seroprevalence of antibodies to Chlamydophila abortus in Ovine in the State of Alagoas, Brazil. Braz J Microbiol 41: 358-364

Rodolakis A, Salinas J, Papp J 1998: Recent advances on ovine chlamydial abortion. BMC Vet Res 29: 275-288

Sachse K, Bavoil PM, Kaltenboeck B, Stephens RS, Kuo CC, Rossello-Mora R, Horn M 2015: Emendation of the family Chlamydiaceae: proposal of a single genus, Chlamydia, to include all currently recognized species. Syst Appl Microbiol 38: 99-103

Samkange A, Katsande TC, Tjipura-Zaire G, Crafford, JE 2010: Seroprevalence survey of Chlamydophila abortus infection in breeding goats on commercial farms in the Otavi Veterinary District, northern Namibia. Onderstepoort J Vet Res 77: 1-5

Selim A 2016: Chlamydia abortus infection in small ruminanats: A review. Asian J Anim VetAdv 11: 587-593

Špičić S, Račić L, Andrijanić M, Duvnjak S, Zdelar-Tuk M,Stepanić M, Cvetnić Z 2015: Emerging cases of chlamydial abortion in sheep and goats in Croatia and Bosnia and Herzegovina. Berl Munch Tierarztl Wochenschr 128: 180-187 
Stuen S, Longbottom D 2011: Treatment and control of chlamydial and rickittsial infections in sheep and goats. Vet Clin North Am Food Anim Pract 27: 213-233

Trávníček M, Kováčová D, Bhide M, Zubrický P, Cislákova L 2003: Detection of IgG antibodies against Chlamydophila abortus in sheep with reproductive disorders. Acta Vet Brno 72: 95-99

Turkish Statistical Institute (TUIK) Web Site 2019. Regional statistics. Available at: https://biruni.tuik.gov.tr/ bolgeselistatistik/sorguSayfa.do?target=degisken. Last modified January 2020. Accessed June 14, 2020

Villagra-Blanco R, Dolz G, Montero-Caballero D, Romero-Zúñiga, JJ 2015: Detection of antibodies against Chlamydophila abortus in Costa Rican sheep flocks. Open Vet J 5: 122-126

Wang FI, Shieh H, Liao YK 2001: Prevalence of Chlamydophila abortus infection in domisticated ruminants in Taiwan. J Vet Med Sci 63: 1215-1220 